\title{
MJN \\ BOTH PEER EDUCATION AND DEMONSTRATION METHOD IMPROVE STUDENT'S KNOWLEDGE IN FIRST AID OF TRAFFIC ACCIDENT
}

\author{
Riyan Dwi Prasetyawan*, Loeki Enggar Fitri, Setyoadi \\ Faculty of Medicine, University of Brawijaya, Indonesia \\ *Corresponding Author's Email: riyandwiprasetyawan@gmail.com
}

\begin{abstract}
Traffic accident has become one of the main problems in the world with increasing numbers of occurrence annually. Traffic accident needs immediate and accurate treatment before main aid from medical staff. First aid becomes important and immediate interventions which a lay person can perform with minimum or without medical equipment. First aid is closely related to knowledge of a lay person. The people's knowledge can be improved through peer education and demonstration methods toward students' knowledge in giving first aid related to traffic accident. This study was quasi experiment with pretest-posttest with control group approach. There were respondents consisting of 48 participants devided into two groups. The data was analyzed by using paired $t$-test and independence sample $t$-test. Questionnaire were used to measure the knowledge before and after intervention. The findings showed improvement on students' knowledge about traffic accident with peer education and demonstration methods respectively $(p=0.000)$. There was no difference in improvement of the knowledge for both methods $(p=0.512)$. Peer education and demonstration methods can be used to improve students' knowledge dealing with first aid of traffic accident.
\end{abstract}

Keywords: Peer Education Method, Student, Knowledge

\section{INTRODUCTION}

Traffic accident is a main problem causing highest death rate in the world. World Health Organization (WHO) predicts that the numbers of deaths caused by traffic accident will increase by $80 \%$ until 2020 (Peden, 2004). Globally, cases of injuries caused by traffic accident is in ninth rank among other cause, and it is predicted to increase until third position in 2020 (Lyons et al.,2008).

Traffic accident patient needs immediate and accurate aids before receiving treatments from medical staff. First aid becomes an important aspect and it is the immediate intervention that can be given by lay person with minimum or without medical equipment (Kumar, Kulkarni \& Hugara, 2013). The purpose of first aid is to provide preliminary relief and to prevent further injury before proper treatment is available (Michaels, 2011). The existing fact shows that lay person are always present and responsive in the spot of the accident than medical staff or ambulance (Heidari, Aryankhesal \& Khorasani-Zavareh, 2018). World Health Organization (WHO) states that lay person is important part of medical emergency treatment in growing countries (Sasser et al., 2005). Lay person can act as first aid provider if an emergency state condition occurs before the arrival of the ambulance (Nelson et al., 2017). Previous studies show that the proportion of patients who received first aid ranged from $10.7 \%$ to $65 \%$. Incorrect first aid was given to $83.7 \%$ of the cases (Tannvik, Bakke \& Wisborg, 2012). As the percentage of error level is high in first aid given in these cases, so improvement of basic knowledge of first aid is necessary through peer-based health education or conventional education to reduce such errors. 
Peer based health education is an active learning involving peers as educators developing an health education strategies about first aid (Toner et al., 2007; Peykari et al., 2011). Peer education is a good method of educating because it is effective to improve self-esteem, competence, and anxiety reduction in learning (Stone, Cooper \& Cant, 2013). Previous studies shows that students trained by peers have equal quality compared to students trained by professionals to train in basic life support (Beck et al., 2015). Meanwhile, conventional health education is demonstration in a manner to make it concrete and interesting (Djamarah, Bahri \& Zain, 2012). However, in case of presenters in health education using lecturing and demonstrations is dominating the learning process then the students become passive in the towards the process of learning (Mubarak et al., 2007). The students involved in lengthy learning process will get bored, as a result their attention towards the presenter gets lowered, leading to lower learning achievement (Djamarah, Bahri \& Zain, 2012).

Preliminary findings by the researcher in Glagah 1 Senior High School, Banyuwangi, with 20 students who were given questionnaire and then followed by interview showed that 13 students have poor understanding of first aid of traffic accident, 10 students never had training of first aid, and 13 students only joined the crowd when an accident occurred. Students who got training in first aid of traffic accident only had the learning material of lecturing and demonstration which they only followed. However, from 10 students who ever joined health education of first aid of traffic accident in the school, stated that they did not fully focus on the given study. Therefore, there is a need to use other method in learning process of first aid of traffic accident. This study aimed to investigate the level of knowledge achieved incase of peer education and demonstration methods toward students' caoability in giving first aid of traffic accident.

\section{METHODOLOGY}

This study used quasi experiment design with pretest-posttest with control group approach. There were 48 respondents from senior high school students and are grouped into peer education as intervention group and demonstration as control group.

The intervention group is grouped into 6 smaller groups consisting of 4 persons. The period of peer education was given for 20 minutes for each study. Meanwhile the control group also only have 20 minutes for each study.

The inclusion criteria of the respondents were, firstly, eleventh graders, willing to learn first aid of traffic accident, giving their consent to participate, without previous health education training of first aid of traffic accident. The questionnaire was used as measurement instrument to determine knowledge level which has been validated and tested for its reliability with alpha Cronbach score 0.75 . The measurement was done before and after the intervention. Bivariate analysis used paired $t$-test and independent sample $t$-test. The study was done after getting ethical clearance from commission of medicine school ethics of Universitas Brawijaya.

\section{RESULTS}

Table 1: Characteristic Distributions of the Respondents based on Ages of Intervention and Control Groups

\begin{tabular}{|l|l|c|c|c|}
\hline Variable & \multicolumn{1}{|c|}{ Groups } & $\mathbf{N}$ & Mean \pm SD & 95\% CI \\
\hline Ages & Intervention & 24 & $16.66 \pm 0.481$ & $16.46-16.87$ \\
& Control & 24 & $16.83 \pm 0.380$ & $16.67-16.99$ \\
\hline
\end{tabular}

Based on table 1, it can be noticed that the averages of the respondents' ages of both the groups were 16 year old with standard deviation 0.481 .

\section{Table 2: The Distributions of the Respondents' Gender and Initial First Socialization}

\begin{tabular}{|l|l|l|c|c|}
\hline Variable & Groups & Categories & N & Percentage (\%) \\
\hline Gender & Intervention & Males & 11 & 45.8 \\
& & Females & 13 & 54.2 \\
\cline { 2 - 5 } & Control & Males & 9 & 37.5 \\
& & Females & 15 & 62.5 \\
\hline Training of & \multirow{2}{*}{ Fintervention } & Ever & 0 & 0 \\
& & Not Yet & 24 & 100 \\
\cline { 2 - 5 } & Control & Ever & 0 & 0 \\
& & Not Yet & 24 & 100 \\
\hline
\end{tabular}

Based on table 2, genders of intervention and control group is dominated by female, 13 respondents $(54.2 \%)$ and 15 respondents $(62.5 \%)$. The characteristics of the respondents based on experience of gaining training of first aid for both teams revealed that none of them got first aid training, 24 respondents (100\%). 
Table 3: Changes in Improvement of Knowledge about First Aid of Traffic Accident by using Peer Education Method

\begin{tabular}{|l|c|c|c|c|}
\cline { 1 - 4 } \multicolumn{1}{|c|}{ Knowledge } & N & Mean \pm SD & $\mathbf{9 5 \% ~ C I ~}$ & \multirow{2}{*}{ P Value } \\
\cline { 1 - 4 } Before & 24 & $41.96 \pm 2.368$ & $40.96-42.96$ & \multirow{2}{*}{0.000} \\
\cline { 1 - 4 } After & 24 & $46.79 \pm 2.413$ & $45.77-47.81$ & \\
\hline
\end{tabular}

Based on the table it can be said that that there is improvement of knowledge about first aid of traffic accident after implementation of peer education method with a $p$ value of $0.000(p<0.05)$,

Table 4: Changes on Knowledge Improvement about First Aid of Traffic Accident with Demonstration Method

\begin{tabular}{|l|c|c|c|c|}
\hline \multicolumn{1}{|c|}{ Knowledge } & N & Mean \pm SD & 95\% CI & P Value \\
\cline { 1 - 4 } Before & 24 & $42.70 \pm 2.678$ & $41.57-43.83$ & \multirow{2}{*}{0.000} \\
\cline { 1 - 4 } After & 24 & $46.37 \pm 1.929$ & 45.56 .47 .18 & \\
\hline
\end{tabular}

Table 4 shows $p$ value $0.000(p<0.05)$ meaning that there is improvement of first aid in case of traffic accident by using demonstration method

Table 5: The Different Changes of Knowledge Improvement about First Aid of Traffic Accident by using Peer Education and Demonstration

\begin{tabular}{|c|c|c|c|c|}
\hline Knowledge & N & Mean \pm SD & 95\% CI & P Value \\
\hline Before intervention & & & & \\
Peer education & 24 & $41.96 \pm 2.368$ & $40.96-42.96$ & 0.309 \\
Demonstration & 24 & $42.70 \pm 2.678$ & $41.57-43.83$ & \\
\hline After Intervention & & & & \\
Peer education & 24 & $46.79 \pm 2.413$ & $45.77-47.81$ & 0.512 \\
Demonstration & 24 & $46.37 \pm 1.929$ & $45.56-47.18$ & \\
\hline
\end{tabular}

Based on the table, $p$ value is $0.512(p>0.05)$ showing that there is no difference of knowledge improvement about first aid of traffic accident by using both methods of peer education and demonstration.

\section{DISCUSSION}

This study showed significant differences in cognitive score after being given health education through peer education. This study is in line with previous study that stated peer education can improve the respondents' knowledge of first aid of traffic accident. Peer education approach can help to improve knowledge about health problem. This approach is useful because peer education empowers the information recipients as educators and learners (Williams and Labonte, 2007). Peer education is found to improve knowledge of the respondents who provide basic health service. A study stated that learning with peers can improve knowledge of senior high school students in providing qualified basic life support (Choi, 2015).

Peer education also facilitates to deliver health educational message reliably and easily because they at equal states and positions. Meanwhile, the given information by medical staff is sometime not easily accepted. Besides that, level of belief and comfort between educators and peers must be balanced to facilitate more transparent and opened discussion. So, information can be delivered easily in this manner. Peer education strategy was implemented among small groups consisting of 4-6 individual for effective discussion and for effective information delivery, so that knowledge level is improved. Such effective information delivery to each member of peer education group are moderately effective at improving knowledge and behavioral outcomes (Medley et al., 2009). The finding is supported by another stating that there is increase in knowledge level related to basic life support after being given health education using peer-based health education method. Respondents can easily interact and discuss with their peers, so information absorption becomes easier for respondents resulting in improvement of knowledge (Abbas et al., 2018). With the improvement of knowledge through this training, the respondents will be able to respond accurately to traffic accident cases and face the challenges (Mobarak, Afifi \& Qulali, 2015).

Findings of this study also explained that there is significant improvement in knowledge level after being given health education method by using demonstration method. It is in line with Salunkhe \& Dias (2014), showing that demonstration is significant to improve respondents' knowledge about first aid in traffic accident. Health education given to police shows that there is significant shortage of knowledge and skills related to basic life support (Salunkhe \& Dias, 2014). Demonstration is a way of presentation using instruments or displaying a certain process, situation, and specific thing making the process of learning easier. The method can be both real or imitative, involving oral explanation (Djamarah, Bahri \& Zain, 2012). By using this method, respondent will learn something concretely, easily, interestingly, and actively to invoke them to be more active in learning resulting in improvement of their knowledge. The improvement of related knowledge 
about basic life support is significant in providing first aid of traffic accident (Hoque et al., 2017).

The findings showed that there was no significant difference in method of learning for both the process toward a lay person's knowledge about first aid of traffic accident for students of Glagah 1 Senior High School, Banyuwangi. Health education for both methods allowed suitable information delivery and appropriate understanding of the respondents. Therefore, health education is crucial and must be given to improve knowledge of first aid in case of traffic accidents. In return, if someone lacks information then it will cause him to have difficulties to deal such situations. Health education about first aid improves score of habitual knowledge to help and improve self-esteem in providing first aid (He, Wynn \& Kendrick, 2014).

Peer education is an effective method in promoting knowledge and healthy attitudes of teenagers. Peer education is related to social development, status equality, values and incorporates hopes among students through preparation, training, supervision, and appropriate evaluation. Through peer education program, health promotion can be conducted (Abdi \& Simbar, 2013). Health education through demonstration method is also significant to improve knowledge about given health information, and it can influence attitudes and health practices. Previous study by Srinivasula et al., in 2018 explained that there is change of knowledge after demonstration method of training with a follow up for next two weeks resulting in improving respondents' knowledge compared to initial score.

Knowledge of first aid of traffic accident is important to be known by lay person. Tannvik et al., (2012) stated that first aid of traffic accident became main intervention to be given to every lay person in preventing worsening case or even death of accident victim. This study is supported by Hoque et al., (2017) stating that first aid done by lay person on minor injuries can prevent morbidity after accident. Therefore, first aid training of lay person is important to provide initial treatment after accident (Hoque et al., 2017).

\section{CONCLUSION}

It can be concluded that there is improvement regarding first aid knowledge in case of traffic accident cases by using peer education and demonstration. There is no difference of the knowledge level acquired for both methods of health education delivery. Therefore these two methods can be used to improve students' knowledge dealing with first aid of traffic accident.

\section{ETHICAL CLEARANCE}

This study received ethical clearance from ethical commission of Faculty of Medicine, Unviersitas Brawijaya, Malang, 03/2019.

\section{REFERENCES}

Abbas, F., Sawaf, B., Hanafi, I., Hajeer, M. Y., Zakaria, M. I., Abbas, W., Alabdeh, F. \& Ibrahim, N. (2018). Peers versus professional training of basic life support in Syria: A randomized controlled trial. BMC Medical Education, 18(1), pp 1-9.

Abdi, F. \& Simbar, M. (2013). The Peer Education Approach in Adolescents- Narrative Review Article. Iranian Journal of Public Health, 42(11), pp 1200-1206.

Beck, S., Issleib, M., Daubmann, A. \& Zöllner, C. (2015). Peer education for BLS-training in schools? Results of a randomized-controlled, noninferiority trial. Resuscitation, 94, pp 85-90.

Choi, H.S. (2015). Peer-assisted learning to train high-school students to perform basic life-support. World Journal of Emergency Medicine, 6(3), pp 186-190.

Djamarah, S.B. \& Zain, A. (2012). Strategi Belajar Mengajar, Edisi revisi, Rineka Cipta, Jakarta.

He, Z., Wynn, P. \& Kendrick, D. (2014). Non-resuscitative first-aid training for children and laypeople: A systematic review. Emergency Medicine Journal, 31(9), pp 763-768.

Heidari, M., Aryankhesal, A. \& Khorasani-Zavareh, D. (2018). Laypeople roles at road traffic accident scenes: a systematic review. International Journal of Injury Control and Safety Promotion, 26(1), pp 1-10. 
Hoque, D.M.E., Islam, M.I., Salam, S.S., Sadeq-Ur Rahman, Q., Agrawal, P., Rahman, A., Rahman, F., El-Arifeen, S., Hyder, A.A. \& Alonge, O. (2017). Impact of first aid on treatment outcomes for non-fatal injuries in rural Bangladesh: Findings from an injury and demographic census. International Journal of Environmental Research and Public Health, 14(7), pp 1-15.

Kumar, S.D., Kulkarni, P. \& Hugara, S. (2013). Perception and Practices Regarding First-Aid Among School Teachers in Mysore. National Journal of Community Medicine, 4(2), pp 349-352.

Lyons, R.A., Ward, H., Brunt, H., Macey, S., Thoreau, R., Bodger, O.G. \& Woodford, M. (2008). Using multiple datasets to understand trends in serious road traffic casualties. Accident Analysis and Prevention, 40(4), pp $1406-1410$.

Medley, A., Kennedy, C., O’Reilly, K. \& Sweat, M. (2009). Effectiveness of peer education interventions for HIV prevention in developing countries: A systematic review and meta-analysis. AIDS Education and Prevention, 21(3), pp 181-206.

Michaels, D. (2011). OSHA Field Safety and Health Manual, Department of Labor, U.S.

Mobarak, A.S., Afifi, R.M. \& Qulali, A. (2015). First Aid Knowledge and Attitude of Secondary School Students in Saudi Arabia. Health, 7(10), pp 1366-1378.

Mubarak, W., Chayatin, N., Rozikin, K. \& Supriadi. (2007). Promosi Kesehatan: Sebuah Pengantar Proses Belajar Mengajar dalam Pendidikan, Graha Ilmu, Yogyakarta.

Peden, M. Scurfield, R., Sleet, D., Mohan, D., Hyder, A.A., Jarawan, E. \& Mathers, C. (2004). World Report on Traffic Injury Prevention. World Health Organization, Geneva. Retieved from: https://apps.who.int/ iris/bitstream/handle/10665/42871/9241562609.pdf;jsessionid=9C65CE579FC55D2E8C7448B8E497C2F6 ?sequence $=1$

Peykari, N., Tehrani, F.R., Malekafzali, H., Hashemi, Z. \& Djalalinia, S. (2011). An Experience of Peer Education Model among Medical Science University Students in Iran. Iranian Journal of Public Health, 40(1), pp 57-62.

Salunkhe, P. \& Dias, R. (2014). Effectiveness of Demonstration Regarding Cardiopulmonary Resuscitation on Knowledge and Practice among Policemen. International Journal of Science and Research, 3(5), pp $213-219$.

Sasser, S., Varghese, M., Kellermann, A. \& Lormand, J.D. (2005). Prehospital Trauma Care Sytems, World Health Organisation, Geneva. Retrieved from: https://www.who.int/violence_injury_prevention/publications/ services/39162_oms_new.pdf

Srinivasula, S., Srilatha, A., Doshi, D., Srikanth Reddy, B. \& Kulkarni, S. (2018). Influence of health education on knowledge, attitude, and practices toward organ donation among dental students. Journal of Education and Health Promotion, 7(157).

Stone, R., Cooper, S. \& Cant, R. (2013). The value of peer learning in undergraduate nursing education: a systematic review. ISRN Nursing, 1-10.

Tannvik, T.D., Bakke, H.K. \& Wisborg, T. (2012). A systematic literature review on first aid provided by laypeople to trauma victims. Acta Anaesthesiologica Scandinavica, 56(10), pp 1222-1227.

Toner, P., Connolly, M., Laverty, L., McGrath, P., Connolly, D. \& McCluskey, D.R. (2007). Teaching basic life support to school children using medical students and teachers in a "peer-training" model-Results of the "ABC for life" programme. Resuscitation, 75(1), pp 169-175.

Triple One Care (2017). First Aid Book, Triple One Care, New Zealand. Retrived from: https://www. tripleonecare.co.nz/

Williams, L. \& Labonte, R. (2007). Empowerment for migrant communities: Paradoxes for practitioners. Critical Public Health, 17(4), pp 365-379. 